\title{
INHIBITORY EFFECT OF NIVALENOL, A TOXIC METABOLITE OF FUSARIUM NIVALE, ON THE GROWTH CYCLE AND BIOPOLYMER SYNTHESIS OF HELA CELLS
}

\author{
KOHICHIRO OHTSUBO*, MASA-ATSU YAMADA** \\ AND MAMORU SAITO*** \\ * Department of Pathology, Faculty of Medicine, the University of Tokyo, \\ Tokyo 113, Japan \\ ** Department of Pathology, National Institute of Health, Tokyo 141, Japan \\ *** Department of Carcinogenesis and Cancer Susceptibility, Institute of \\ Medical Science, the University of Tokyo, Tokyo 108, Japan
}

(Received: March 26th, 1968)

\begin{abstract}
SUMMARY : Nivalenol, a toxic product isolated from the rice grains infected with Fusarium nivale, was shown to inhibit the multiplication of HeLa cells completely at a concentration of $0.5 \mu \mathrm{g} / \mathrm{ml}$ or higher. At the concentration of $5 \mu \mathrm{g} / \mathrm{ml}$, protein and DNA syntheses were almost entirely suppressed, whereas little or no inhibition took place in RNA synthesis. The inhibitory effects on both DNA and protein syntheses were similar with respect to the rapidity and severity.

Cell cycle analysis revealed that, in addition to direct effect on $\mathrm{S}$ phase, the toxin affected the entry of $\mathrm{G} 1$ cells into $\mathrm{S}$ phase and that of G2 cells into mitosis. These results are discussed with special reference to the similarity of the action to that of well-known inhibitors for protein synthesis.
\end{abstract}

\section{INTRODUCTION}

From the rice grains artificially infected with a red mold, Fusarium nivale, a metabolic product highly toxic to mice has recently been isolated by Tatsuno and his colleagues (1968). With a dose of $100 \mu \mathrm{g}$ by intraperitoneal route, the purified product killed mice within a few days. This toxin, designated as nivalenol, was purified from the moldy grains by absorption on active carbon column followed by elution with methanol, and isolated on Kieselguhr column with a chloroform-methanol mixture $(5: 1)$ (Tatsuno et al., 1968). An evident effect of the toxin was inhibiton of protein synthesis in vitro and morphological impairment of rapidly growing tissues such as the small intestine and bone marrow in animals.

In the present paper, the effect of nivalenol on growth cycle and biopolymer syntheses of HeLa cells in culture has been studied to elucidate a precise mechanism of the toxic effect on the living matter. Another toxic product, fusarenone, with chemical nature different from nivalenol, has also been isolated from the same infected grains by Morooka

* 大坪 浩一郎 (東京大学医学部病理学教室)

Present address : Department of Carcinogenesis and Cancer Susceptibility, Institute of Medical Science, the University of Tokyo, P. O. Takanawa, Tokyo

** 山田 正篤 (国立予防衛生研究所病理部)

*** 斉藤 守 (東京大学医科学研究所癌体質学研究部) 
and his colleagues (Tsunoda et al, 1967), which has also been studied in comparison with nivalenol.

\section{MATERIALS AND METHODS}

Cell culture system: The experiments were carried out mainly on HeLa S3 cells grown in medium consisting of Eagle's MEM and calf serum at $10 \%$. The concentration of bicarbonate was adjusted to $1 \mathrm{~g} / 1$ for obtaining $\mathrm{pH} 7.3$ of the medium under a humid atomosphere of $5 \% \mathrm{CO}_{2}$ in air. In this growth medium, HeLa S3 cells in log phase showed a doubling time of 24 to $28 \mathrm{hr}$ according to batches of sera and minor variation in culture conditions. The duration of each compartment in a growth cycle was estimated to be as follows: S phase, 7 to $8 \mathrm{hr}$; G2, $4 \mathrm{hr} ; \mathrm{M}, 1 \mathrm{hr}$; and G1, 11 to $15 \mathrm{hr}$. In an experiment, as will be described in the text, KB cells were employed instead of HeLa S3 cells. The doubling time of the cell line was almost similar to that of HeLa cells in the growth condition mentioned above.

Chemicals employed: Chemicals were obtained from the following sources: the radioactive precursors, Radiochemical Center, Amersham, England; colcemid, Ciba Pharmaceutical Company; cycloheximide, Kaken Chemicals, Co., Tokyo. Puromycin was given by the courtesy of Prof. N. Tanaka, Institute of Applied Microbiology, the University of Tokyo. Nivalenol and fusarenone were gifts from Prof. Tatsuno, Department of Microbial Chemistry, Faculty of Pharmaceutical Sciences, Science University of Tokyo and Dr. N. Morooka, Department of Fcod Research, National Institute of Health, Tokyo, respectively.

Growth measurement: The seed suspension was prepared with the growth medium at the concentration of $0.5 \times 10^{4}$ cells $/ \mathrm{ml}, 1.9 \mathrm{ml}$ of which was delivered into $30-\mathrm{mm}$ glass Petri dishes. The dishes were then incubated at $37^{\circ} \mathrm{C}$ in a $\mathrm{CO}_{2}$ cabinet. On the second day of cultivation when the cells had grown in a logarithmic way, the cultures were added with $0.1 \mathrm{ml}$ of the toxic metabolite at various concentrations and reincubated. Every other day thereafter, two dishes were harvested with $0.05 \%$ trypsin (Nutritional Biochemical Corp., $1: 300$ ) and the number of cells per dish was counted by a hemocytometer (Eosinophile counting chamber, Kayagaki Works, Co., Tokyo).

Estimation of entry of cells into mitosis: For studying the effect on entry of G2 cells (the cells in pre-mitotic phase) into mitosis, we have applied the method with "collection function" devised by Puck and Steffen (1963). In a $\mathrm{CO}_{2}$ cabinet, $1 \times 10^{5}$ cells were cultivated with $2.3 \mathrm{ml}$ of the medium in $30-\mathrm{mm}$ Petri dishes. Two days later, $0.1 \mathrm{ml}$ of colcemid solution at $12.5 \mu \mathrm{g} / \mathrm{ml}$ and $0.1 \mathrm{ml}$ of the toxic metabolite at various concentrations were added to the cultures simultaneously. At 2 -hr intervals, 2 dishes were treated with trypsin for respective groups. The cells thus harvested were treated with a hypotonic saline solution, fixed with an ethanol-acetic acid mixture $(3: 1)$ and mounted onto slides. After staining the cells with Giemsa, the fraction of the cell population in mitosis was counted and the accumulation of mitotic figures exposed to colcemid was expressed by the mitotic collection function.

When the cells were exposed to colcemid at a suitable concentration with which all the mitosis can be retained and no processes can be inhibited in the interphase, the mitotic figures accumulated gradually as a function of time. Since the mitotic collection function is defined by the quantity, $\log \left(1+N_{M}\right)$, where $N_{M}$ is the fraction of the cell population in mitosis, the function would virtually represent the logarithm of increase 
in cell number when the cells were not treated with colcemid. The doubling time was estimated by the time length for the collection function reaching $\log 2$.

Estimation of the flow rate from $G 1$ phase to $S$ : In a series of experiments similar to the former one, ${ }^{3} \mathrm{H}$-thymidine $(0.5 \mu \mathrm{Ci} / \mathrm{ml})$ was added to the medium simultaneously with colcemid. Every $2 \mathrm{hr}$ the cells were harvested and mounted onto slides. After processed autoradiographically, the fraction of labeled cells were counted. Since the population is constant by the addition of colcemid during the observation period, the increase in the fraction of labeled cells really represents the fraction of the cells which began to synthesize DNA within a given time or the flow rate from G1 phase to $\mathrm{S}$.

Incorporation of the radioactive precursors into biopolymers: The synthetic rate of biopolymers was assayed by the "coverslip technique" of Baltimore and Franklin (1962) which has been slightly modified as follows: By the use of a 1-ml pipette, $0.3 \mathrm{ml}$ of the cell suspension $\left(1 \times 10^{5} / \mathrm{ml}\right)$ was placed in a drop on $18-\mathrm{mm}$ round coverslips in $30-\mathrm{mm}$ Petri dishes in replicate. The dishes were incubated overnight in a $\mathrm{CO}_{2}$ cabinet. After the cells had been attached onto coverslips, $1.6 \mathrm{ml}$ of the growth medium was added to them. The cells were reincubated for another day to grow logarithmically. The cells were then incubated with $0.1 \mathrm{ml}$ of the radioactive precursors for $1 \mathrm{hr}$ and fixed with an ethanol-acetic acid mixture $(3: 1)$. After each coverslip was extracted with four changes of cold $2 \%$ PCA for $10 \mathrm{~min}$, rinsed in running tap water for $15 \mathrm{~min}$, and air-dried, it was placed in planchet to count the radioactivity by a window-less gasflow counter (Aloka Type JDC-104, Japan Radiation and Medical Electronics, Inc., Tokyo). The final concentrations of the radioactive precursors were as follows: ${ }^{3} \mathrm{H}$ thymidine for DNA, $0.5 \mu \mathrm{Ci} / \mathrm{ml}$ (specific activity, $5 \mathrm{Ci} / \mathrm{mM}$ ), ${ }^{3} \mathrm{H}$-uridine for RNA, 1.0 $\mu \mathrm{Ci} / \mathrm{ml}(3.3 \mathrm{Ci} / \mathrm{mM})$ and ${ }^{3} \mathrm{H}$-leucine, -arginine or -tryptophan for protein, $1.0 \mu \mathrm{Ci} / \mathrm{ml}$ $(0.24 \mathrm{Ci} / \mathrm{mM}, \quad 0.24 \mathrm{Ci} / \mathrm{mM}$ and $0.88 \mathrm{Ci} / \mathrm{mM}$, respectively). In the assay of protein synthesis, the medium was replaced with $1.9 \mathrm{ml}$ of the specified amino acid free MEM containing $10 \%$ calf serum $2 \mathrm{hr}$ before incorporation of the radioactive amino acid.

Under the condition of the assay described above, the incorporation of ${ }^{3} \mathrm{H}$-thymidine was found to be proportional to the number of cells used and linear with the time of exposure for at least $2 \mathrm{hr}$. In the case of ${ }^{3} \mathrm{H}$-uridine and -amino acids, there was time lag less than 10 minutes because of the possible presence of precursor pool for RNA and for protein, both larger than that for DNA.

For studying the effect of toxic metabolite on biopolymer syntheses, $0.1 \mathrm{ml}$ of the metabolite solution was added to the Petri dishes, 2 to 3 dishes for each concentration, one $\mathrm{hr}$ before the incubation with radioactive precursors. In this case, $1.5 \mathrm{ml}$ of the growth medium instead of $1.6 \mathrm{ml}$ was added to the culture on the second day of cultivation. In a short-term incorporation experiment, the metablite was added to the cultures simultaneously with the radioactive precursors $(0.1 \mathrm{ml}$ each for $1.8 \mathrm{ml}$ of the medium) and sampling was made every 15 min.

\section{RESULTS}

\section{Inhibition of Cell Multiplication by the Toxic Metabolite}

Three concentrations of nivalenol $(0.05,0.5$ and $5 \mu \mathrm{g} / \mathrm{ml})$ were tested with HeLa cells in replicate culture. As shown in Fig. 1, the multiplication of cells was completely inhibited when the cells were exposed to a concentration of $0.5 \mu \mathrm{g} / \mathrm{ml}$, and kept at or 


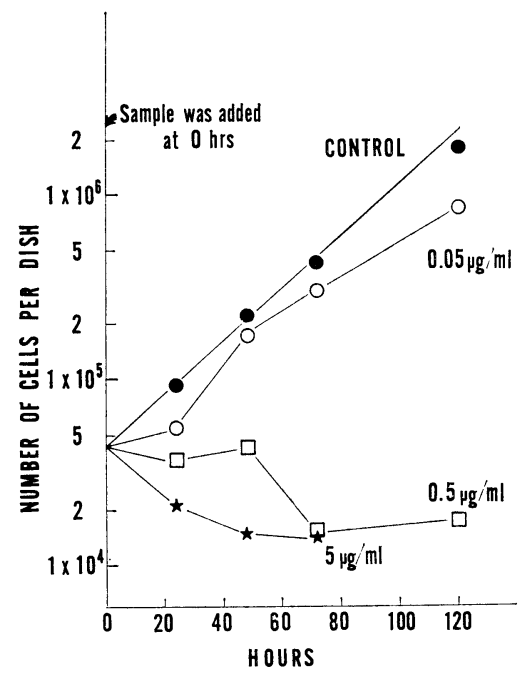

Fig. 1. Inhibition of multiplication of HeLa S3 cells by nivalenol.

Nivalenol was added to the medium at $0 \mathrm{hr}$ at the concentrations as follows : $0.05 \mu \mathrm{g} / \mathrm{ml}(\mathrm{O}) ; 0.5(\square) ; 5(\star)$ and control

close to the given initial level. At $0.05 \mu \mathrm{g} / \mathrm{ml}$, the growth was delayed on the 24 th $\mathrm{hr}$, and followed by rapid increase in cell number.

\section{Inhibition of Entry of Cells into Mitosis by the Toxic Product}

When the log-phase HeLa cells were exposed to colcemid, the collection function was found to be a straight line with a short time lag (Fig. 2). The doubling time of the non-treated HeLa cells was estimated to be $27 \mathrm{hr}$. With nivalenol at a concentration of $0.05 \mu \mathrm{g} / \mathrm{ml}$, the collection function lags first 2 to $4 \mathrm{hr}$, and then begins to increase. With two higher doses $(0.5$ and $5 \mu \mathrm{g} / \mathrm{ml})$, no actual mitosis accumulates immediately after the cells are exposed to the toxin, suggesting that the cells are blocked in G2

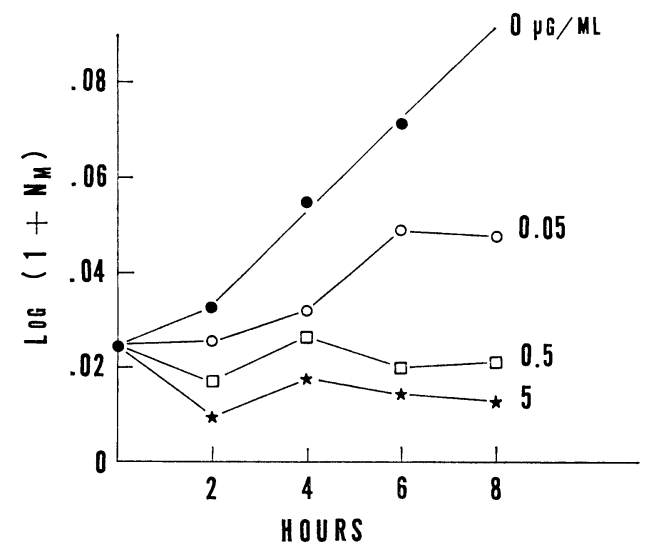

Fig. 2. The changes in the mitotic collection function of HeLa S3 cells produced by nivalenol.

For explanation of symbols, see the legend to Fig. 1. 
phase just prior to $\mathrm{M}$ phase.

\section{Effect of Nivalenol on the Entry of G1 Cells into $S$ Phase}

In the non-treated control cultures, the fraction of labeled cells on autoradiograph increases as a function of time (Fig. 3). Since the cell cycle is blocked at the mitotic phase by addition of colcemid simultaneously with ${ }^{3} \mathrm{H}$-thymidine, the increase of labeled cells really represents that of $\mathrm{G} 1$ cells entering into the $\mathrm{S}$ phase during a given period. As shown in Fig. 3, the flow rate from G1 phase to $S$ is constant in the non-treated cultures.

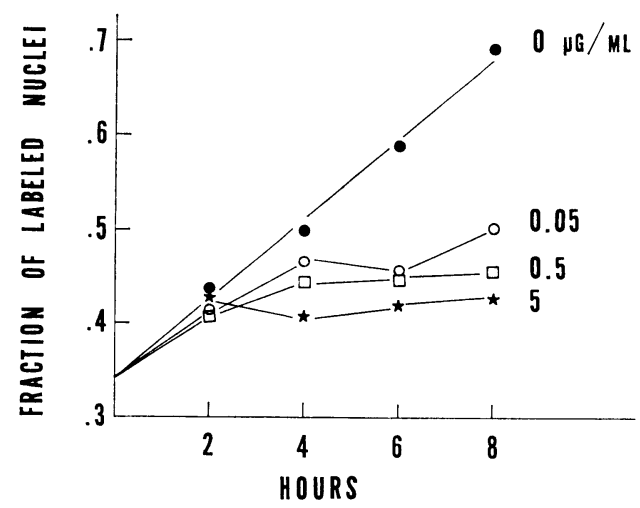

Fig. 3. The changes in the flow rate from G1 phase to $S$ of HeLa S3 cells produced by nivalenol.

For explanation of symbols, see the legend to Fig. 1.

In the experimental groups the fraction of labeled cells at any concentrations increases at least for $2 \mathrm{hr}$ at a rate corresponding to that in the control cultures, though the mean number of grains over nucleus decreases according to the concentrations. Two to $4 \mathrm{hr}$ after addition of nivalenol, the fraction labeled reaches a plateau with the two higher doses. At $0.05 \mu \mathrm{g} / \mathrm{ml}$, the fraction labeled seems to be slightly increasing thereafter. At any rate, it has been shown here that nivalenol exhibits G1 block about $2 \mathrm{hr}$ ahead of the S phase so as to hinder G1 cells from entering into the S phase.

\section{Effect of the Toxin on Biopolymer Synthesis}

As shown in Fig. 4, the incorporation of ${ }^{3} \mathrm{H}$-thymidine and -leucine is depressed with nivalenol almost entirely to the minimum at the concentration of $5 \mu \mathrm{g} / \mathrm{ml}$ or higher. In contrast to these, the incorporation of ${ }^{3} \mathrm{H}$-uridine is inhibited by the same concentration only slightly, by 10 to $20 \%$. With the lower concentrations, depression in uptake is lesser, and with the least concentration of $0.005 \mu \mathrm{g} / \mathrm{ml}$ little or no inhibition takes place with any precursors. This tendency was confirmed in the repeated experiments, which are depicted by individual symbols in the figure. The $50 \%$ inhibition doses of the toxin were $0.3,0.4$ and more than $50 \mu \mathrm{g} / \mathrm{ml}$ for ${ }^{3} \mathrm{H}$-thymidine, -leucine and -uridine, respectively. The results indicate that DNA and protein syntheses are inhibited by the toxin in a similar manner, but RNA synthesis to a far lesser extent.

To analyze the toxic effect further, a short-term incorporation experiment was conducted with ${ }^{3} \mathrm{H}$-thymidine and -leucine under the influence of the toxin at $5 \mu \mathrm{g} / \mathrm{ml}$ (Fig. 5). All the cultures were added with either radioactive precursor at $0 \mathrm{hr}$ simultaneously 


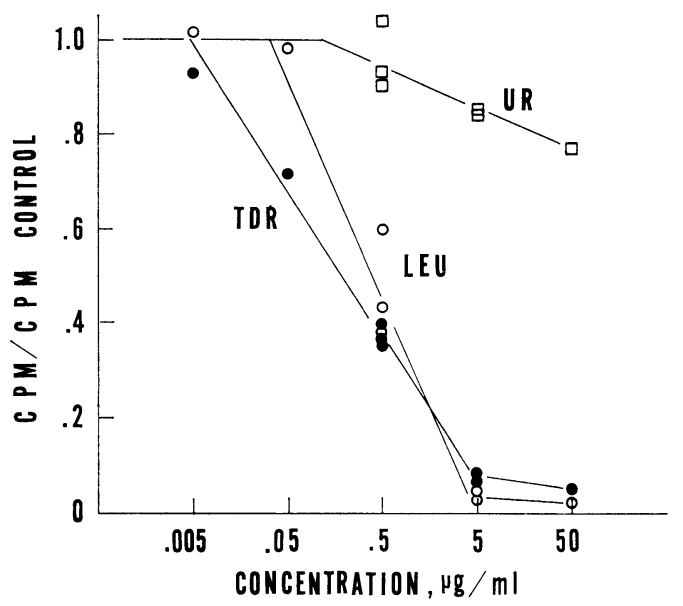

Fig. 4. Effect on incorporatioan of precursors into nucleic acids and protein.

Nivalenol was added to the culture at various concentrations indicated in abscissa and incubated for $1 \mathrm{hr}$. Then the cells were incubated for another hour with ${ }^{3} \mathrm{H}$-thymidine $(\bullet)$, -uridine $(O)$ or -leucine $(\square)$ and fixed. Each symbol represents the average of 3 separate cultures.

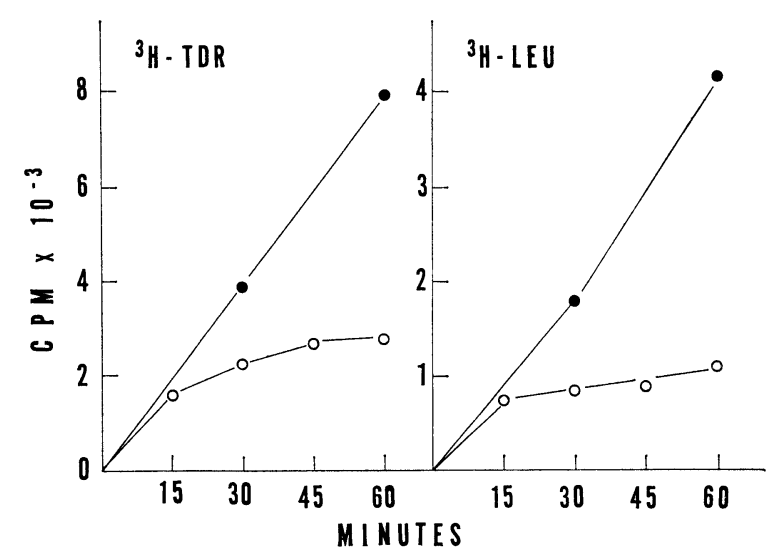

Fig. 5. Immediate inhibition of DNA and protein syntheses by nivalenol.

Tritiated thymidine $(0.5 \mu \mathrm{Ci} / \mathrm{ml})$ or ${ }^{3} \mathrm{H}$-leucine $(1 \mu \mathrm{Ci} / \mathrm{ml})$ was added to the medium at $0 \mathrm{~min}$ simultaneously with nivalenol $(5 \mu \mathrm{g} / \mathrm{ml})$ and the cells were fixed after incubation period indicated in abscissa. non-treated control; and $O$, nivalenol-treated. Each symbol represents the average of 3 separate cultures.

with the toxin. At 15-min intervals up to $60 \mathrm{~min}, 2$ coverslips were taken and the radioactivity was counted after removal of acid-soluble substances.

Incorporation curve of control cultures is shown to be linear within $60 \mathrm{~min}$. In the case of the nivalenol-treated cultures, incorporation of both precursors in the first $15 \mathrm{~min}$ is slightly reduced as compared with control, and rapidly decreases thereafter. The time courses of the depression in uptake of ${ }^{3} \mathrm{H}$-thymidine and -leucine 
seem to coincide with each other. Looking minutely, inhibition of DNA synthesis was found to be preceded slightly by that of protein synthesis; per cent inhibition of the uptake for ${ }^{3} \mathrm{H}$-thymidine and -leucine was 58 and $46 \%$ at $30 \mathrm{~min}$, and 35 and $25 \%$ at $60 \mathrm{~min}$, respectively. Furthermore, we obtained similar results ${ }^{3} \mathrm{H}$-tryptophan or -arginine instead of ${ }^{3} \mathrm{H}$-leucine. It is noteworthy that, as far as our experimental system is concerned, DNA synthesis is inhibited by the toxin almost as rapidly as protein synthesis.

\section{Comparison of Fusarenone with Nivalenol in the Effect on Biopolymer Syntheses}

Fusarenone, a toxic metabolite of Fusarium nivale isolated by Morooka and his colleagues (Tsunoda et al., 1967), was shown to have a slightly different chemical nature from nivalenol. We have here compared fusarenone with nivalenol in the effects on biopolymer syntheses. Log-phase KB cells were incubated for $1 \mathrm{hr}$ with both toxins at a concentration of $0.5 \mu \mathrm{g} / \mathrm{ml}$ and then with tritiated precursors for another hr. Incorporation of the radioactive precursors into nucleic acids and protein was counted by a window-less gasflow counter after removal of acid soluble substances. Table 1 shows that fusarenone also inhibits protein and DNA syntheses to a similar extent but little RNA synthesis, and the effect appears to be slightly higher than that of nivalenol.

Table 1. Inhibitory effect of fusarenone on the biopolymer syntheses of $\mathrm{KB}$ cells as compared with that of nivalenol

\begin{tabular}{|c|c|c|c|c|c|c|}
\hline \multirow{2}{*}{ Samples added } & \multicolumn{6}{|c|}{ Rate of Incorporation (C. P. M.) of } \\
\hline & \multicolumn{2}{|c|}{${ }^{3} \mathrm{H}$-Tryptophan } & \multicolumn{2}{|c|}{${ }^{3} \mathrm{H}$-Thymidine } & \multicolumn{2}{|c|}{${ }^{3} \mathrm{H}$-Uridine } \\
\hline \multirow{3}{*}{ Control } & 1069 & & 2669 & & 1228 & \\
\hline & 947 & 976 & 2886 & 2782 & 1168 & 1292 \\
\hline & 913 & & 2791 & & 1479 & \\
\hline \multirow{3}{*}{ Fusarenone, $0.5 \mu \mathrm{g} / \mathrm{ml}$} & 234 & & 478 & & 1289 & \\
\hline & 177 & 184 & 414 & 432 & 1075 & 1164 \\
\hline & 141 & $(19 \%)$ & 436 & $(16 \%)$ & 1129 & $(94 \%)$ \\
\hline \multirow{3}{*}{ Nivalenol, $0.5 \mu \mathrm{g} / \mathrm{ml}$} & 372 & & 977 & & 1114 & \\
\hline & 326 & 341 & 1143 & 1081 & 1041 & 1117 \\
\hline & 326 & $(35 \%)$ & 1123 & $(38 \%)$ & 1195 & $(90 \%)$ \\
\hline
\end{tabular}

Log-phase $\mathrm{KB}$ cells were incubated with each sample at the concentration of $0.5 \mu \mathrm{g} / \mathrm{ml}$ for $1 \mathrm{hr}$ and then with tritiated precursors for $1 \mathrm{hr}$. After removal of acid soluble substances, the radioactivity was counted by a window-less gasflow counter. Figures on the left in column of each precursor represent c. p. m. of individual coverslip cultures and those on the right the mean of the three figures. Figures in parenthesis indicate the percentage of the control.

\section{DisCUSSION}

In this paper, data have been presented to demonstrate that nivalenol markedly inhibits the incorporation of amino acids into protein and thymidine into DNA but not uridine into RNA under the same condition. Unexpectedly, the inhibition of protein and DNA syntheses was shown to be of the same degree for dose-response curve (Fig. 4) and, with a higher dose, both inhibitions took place so rapidly that a temporal rela- 
tionship between the initiation of the two processes has not yet been established (Fig. 5).

Here a question is raised concerning the primary action of the toxin: whether a mechanism common to both protein and DNA syntheses is affected or the two inhibitions occur independently. Using cell cycle analysis, we were able to demonstrate G1 and G2 blocks in addition to the effect on the S or DNA synthetic phase (Figs. 2 and 3). In the intestinal mucosa of mice, G2 block was also evident (Saito et al., 1967). It would be unlikely that prevention of DNA synthesis quits protein synthesis. On the other hand, the inhibition of protein synthesis could induce inhibition of DNA synthesis because enzymes required for DNA synthesis are not produced. The activity levels of some enzymes such as thymidine kinase was reported to rise after the cells began the duplication of their DNA (Brent, T. P., Butler, J. A. V. and Crathorn, A. R., 1965 ; Stubblefield and Murphree, 1967). This would explain the rapidity in the indirect inhibition of DNA synthesis.

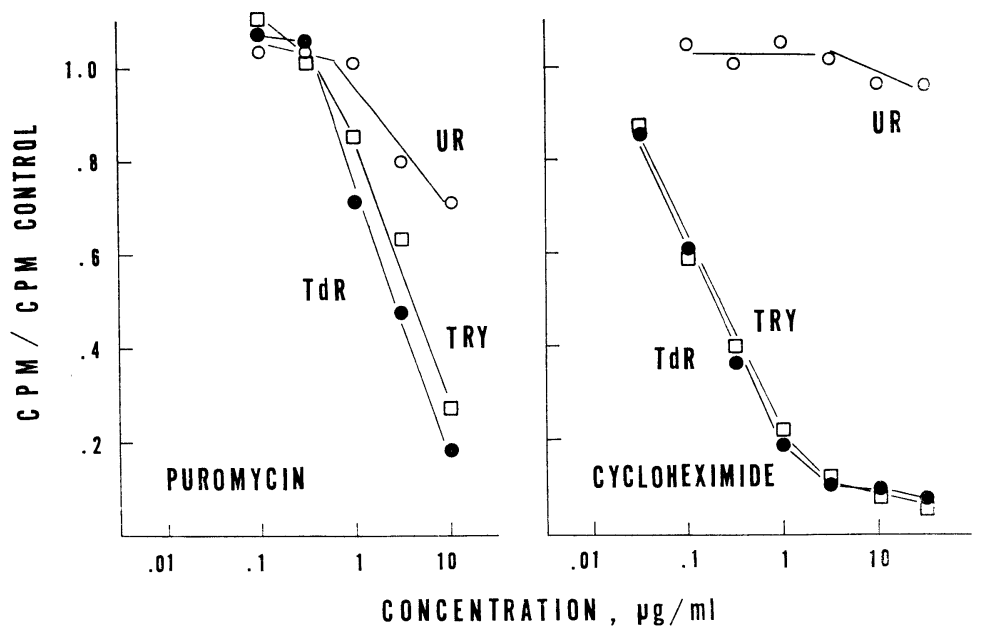

Fig. 6. Effect of puromycin and cycloheximide on the biopolymer syntheses of HeLa S3 cells.

The culture was added with puromycin (left figure) or cycloheximide (right figure) and incubated for $1 \mathrm{hr}$. Then the culture was incubated for additional one $\mathrm{hr}$ with ${ }^{3} \mathrm{H}$-thymidine $(\bullet)$, -uridine $(\mathrm{O})$ or -tryptophan $(\square)$ and fixed. Each symbol represents the average of 3 separate cultures.

It is well known that cycloheximide completely suppresses the synthesis of DNA as well as protein in Saccharomyces at the minimum growth inhibitory concentration, whereas the synthesis of RNA continues for a while after the addition of the antibiotic to the culture (Kerridge, 1958; Siegel and Sisler, 1964). They concluded that the primary action of the antibiotic is the prevention of protein synthesis and that on other cellular metabolisms including DNA synthesis reflects the disruption of protein synthesis. Bennett, Smithers and Ward (1964) observed with mammalian cells in culture (H. Ep. No. 2) that, under all experimental conditions employed, the syntheses of both protein and DNA were rapidly and apparently simultaneously depressed by cycloheximide. They also analysed the mechanism most carefully and pointed out two possibilities : the inhibition of these two synthetic processes may be related with each other or may reflect independent actions of the inhibitor. Using the experimental system with HeLa S3 
cells, we have confirmed such a dual inhibitory effect on DNA and protein syntheses by cycloheximide as by nivalenol, the same tendency being demonstrated with puromycin (Fig. 6).

Contradictory to the results obtained by Bennett et al. (1964) and by us in the present paper, Mueller and others (1962) indicated the fact, that puromycin, at a level which inhibits $90 \%$ of the protein synthesis, partly blocks DNA synthesis in their amethopterinsynchronized HeLa S3 cells. They found that, immediately after reversal of the thymidine-less state by addition of thymidine, synchronized DNA synthesis initiated at slow rate, followed by the acceleration to approximately two times the initial rate after 1 to $2 \mathrm{hr}$. Synthesis was discontinuous in that it stopped in $6 \mathrm{hr}$ when one replication had taken place. Even if puromycin $(10 \mu \mathrm{g} / \mathrm{ml})$ was added at the time of thymidine addition, DNA synthesis began and continued for at least $6 \mathrm{hr}$ at the initial slow rate. Furthermore, when puromycin was added $4 \mathrm{hr}$ after the onset of DNA synthesis, the cells were shown to synthesize the remainder of the DNA completely. In other words, early DNA synthesis appears to occur by pre-existing mechanism(s) such as enzyme production, and puromycin would inhibit only the acceleration of DNA synthesis at the late stage.

Considering that cells in the logarithmic growth phase may not have such pre-existing mechanism(s), the discrepancy between the data obtained by Mueller et al. (1962) and ours would be plausibly explained. In cells growing logarithmically, DNA synthesis would take place in more close association with protein synthesis as compared with in synchronized, metabolically unbalanced cells. Using the fertilized sea urchin egg, Black, Baptist and Piland (1967) have beautifully demonstrated that association of protein synthesis with DNA replication differs according to the stage of fertilization, namely, to the quantity of pre-existing mechanism(s); the embryo must synthesize proteins in order to synthesize DNA in the given duplication cycle, but, in early stages, these proteins may be synthesized about one cycle in advance of their utilization. In late cleavage puromycin was found to inhibit protein synthesis strongly a few minutes in advance of DNA synthesis.

Histological examination of mice injected with nivalenol revealed the destruction of cells in the bone marrow, intestinal mucosa and others in which DNA was actively synthesized. The same observation has been reported with puromycin and cycloheximide (Estensen, and Baserga, 1966 ; Verbin, and Farber, 1967).

All of these data taken together, there may be no confliction with the idea that the action of nivalenol is quite similar to that of puromycin or cycloheximide. Ueno and others (1968) have shown that the nivalenol inhibits protein synthesis in a cell-free system with the rabbit reticulocytes, indicating that the toxin is a potent, direct inhibitor for protein synthesis in animal cells. As to DNA synthesis of Ehrlich ascites tumor cells, they have found that nivalenol has no direct effect on DNA polymerase reaction in vitro. In view of all the above informations, it is more likely that the inhibition of protein synthesis would be the primary cause for the toxic effect which secondarily produces the suppression of DNA synthesis.

\section{ACKNOWLEDGEMENT}

We acknowledge Dr. T. Tatsuno, Department of Microbial Chemistry, Faculty of Pharmaceutical Sciences, Science University of Tokyo, and Dr. N. Morooka, Department of Food Research, National Institute of Health, for their kind supply of purified toxic metabolites of 
Fusarium nivale. We thank Dr. Y. Egashira, Chief of Department of Pathology, National Institute of Health, for his courtesy of aiding one of us (K. O.) in carrying out this work in his Department. This work has been party supported by a grant from the Japanese Ministry of Education (No. 94040).

\section{REFERENCES}

BAltimore, P. AND Franklin, R. M. (1962): The effect of mengo virus infection on the activity of the DNA dependent RNA polymerase of L-cells. Proc. Natl. Acad. Sci., 48, 1383-1390.

BennetT, L. L., Jr., Smithers, D. AND WARD, C. T. (1964) : Inhibition of DNA synthesis in mammalian cells by actidione. Biochim. Biophys. Acta, 87, 60-69.

Black, R. E., Baptist, E. AND Piland, J. (1967): Puromycin and cycloheximide inhibition of thymidine incorporation into DNA of cleaving sea urchin eggs. Exptl. Cell Res., 48, 431-439.

Brent, T. P., Butler, J. A. V. AND CRAThorn, A. R. (1965) : Variations in phosphokinase activities during the cell cycle in synchronous populations of HeLa cells. Nature, 207, 176-177.

Estensen, R. D. AND BAseRga, R. (1966): Puromycin induced necrosis of crypt cells of the small intestine of mouse. J. Cell Biol., 30, 13-22.

KERRIDGE, D. (1958): The effect of actidione and other antifugal agents on nucleic acid and protein synthesis in Saccharomyces carlsbergensis. J. Gen. Microbiol., 19, 497-506.

Mueller, G. C., Kajiwara, K., Stubblefield, E. AND Rueckert, R. R. (1962) : Molecular events in the reproduction of animal cells. I. The effect of puromycin on the duplication of DNA. Cancer Res., 22, 1084-1090.

Saito, M., Enomoto, M., Yokoyama, T., Ohtsubo, K., Yamaguchi, K. and Tatsuno, T. (1967): Studies on the lesion in the intestinal mucosa and bone marrow of mice caused by a toxic metabolite of Fusarium nivale. Tr. Soc. Path. Japon., 56, 78.

Siegel, M. R. AND Sisler, H. D. (1964): Site of action of cycloheximide in cells of Saccharomyces pastorianus. I. Effect of the antibiotic on cellular metabolism. Biochim. Biophys. Acta., 87, 70-82.

Stubblefield, E. AND Murphree, S. (1967): Synchronized mammalian cell culture. II. Thymidine kinase activity in colcemid synchronized fibroblasts. Exptl. Cell Res., 48, 652-656.

Tatsuno, T., Saito, M. And Okubo, K. : Nivalenol, a toxic principle of Fusarium nivale. Nature, in press.

Tsunoda, H. Toyazaki, N., Morooka, N., Nakano, N., Yoshiyama, H., Okubo, K. And IsODA, M. (1967): Researches on the microorganisms which deteriolate the stored cereals and grains (Part 33). Detection of injurious strains and properties of their toxic substance of scab, Fusarium blight grown on the wheat. Reports of the Food Research Institute, Ministry of Agriculture and Forest. Tokyo, Japan, 23, 89-116.

Ueno, Y., Hosoya, M., Morita, Y., Ueno, I. and Tatsuno, T. (1968) : Inhibition of the protein synthesis in rabbit reticulocyte by nivalenol, a toxic principle isolated from Fusarium nivale-growing rice. J. Biochem. (Tokyo), in press.

VERBIN, R. S. AND FARBER, E. (1967): Effect of cycloheximide on the cell cycle of the crypts of the small intestine of the rat. J. Cell Biol., 35, 649-658. 